\title{
The Railroad Timetable: A Neglected Research Source
}

H. ROGER GRANT

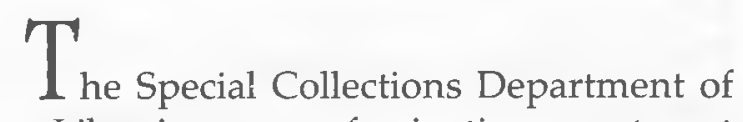
The University of Iowa Libraries owris a fascinating assortment of American railroad timetables in the John P. Vander Maas Collection of Railroadiana. They are especially wide-ranging and are richest for Midwestern or "Granger" carriers.

While most people are familiar with airline and perhaps intercity bus timetables, they probably know little about railroad schedules before the appearance of Amtrak folders. When Amtrak (officially the National Railroad Passenger Corporation) emerged on 1 May 1971, it revolutionized passenger schedules. Except for The Official Railway Guide, designed mainly for railroad personnel, never before had a single national timetable been issued for public consumption. Earlier, however, hundreds of railroads produced thousands of separate folders.

Railroad schedules are nearly as old as the industry itself. When steamcars debuted in the early 1830s, companies like the Baltimore \& Ohio, South Carolina, and Western Railway of Massachusetts prepared printed listings of arrival and/or departure times for station stops. Usually these tiny pikes operated only several score of miles, and their timetables were simple one-sheet broadsides. Undoubtedly inspired by contemporary stagecoach and steamboat poster-type schedules, railroad timetables were not intended for personal possession. Rather these broadsides, often measuring 10 by 15 inches or more, adorned depot walls and likely those of other public 
For Bargains in Farm Lands see Warner \& Andrus, Mountain Lake, Cottonwood Co., Minn.

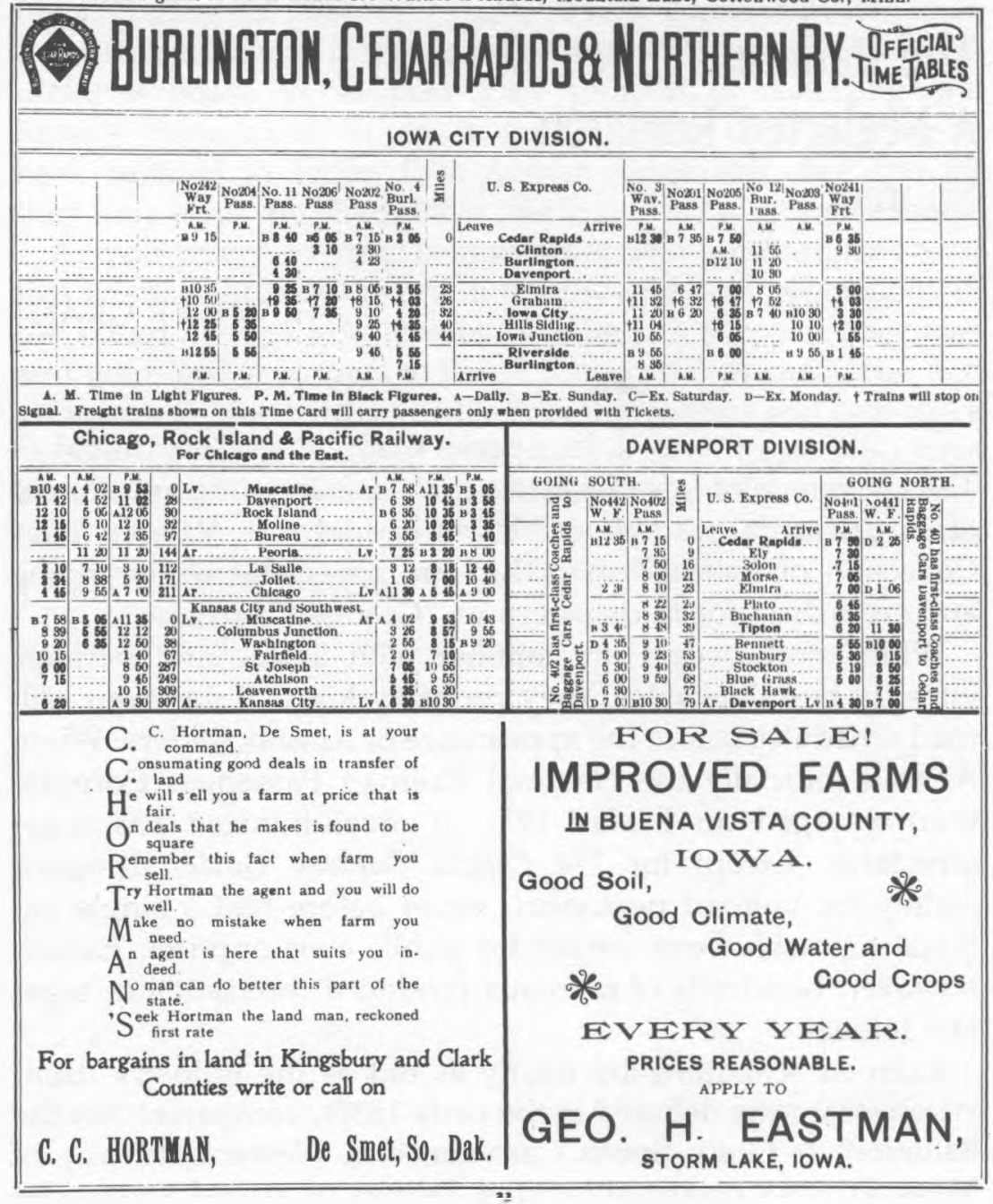


places: hotels, general stores, and the like. Early timetables might be designed for employees as well; some listed the principal operating rules, usually on the reverse side. This was understandable since many of these roads hauled freight shipments and passengers - "hogs and humans" - in the same "mixed" train.

But as railroad companies grew and systems developed, particularly after the Civil War, broadsides no longer served effectively either travelers or employees. Traffic burgeoned and so did the need for more specialized formats. What became common then were separate public and operating (employee) schedules.

A good illustration of the nineteenth century public timetable is one that dates from 1892 for the Burlington, Cedar Rapids \& Northern Railway (BCR\&N), the self-proclaimed "Iowa Route." This company, nee Burlington, Cedar Rapids \& Minnesota and after 1902 part of the Chicago, Rock Island \& Pacific (Rock Island) Railroad, operated approximately 1,300 route miles in Iowa, Minnesota, and South Dakota. Its main line extended from Burlington, Iowa, through Cedar Rapids to Albert Lea, Minnesota, a distance of 253 miles, and forged a direct connection between St. Louis and the Twin Cities. This schedule duly lists all stations and all passenger trains. And it includes those of "way freights" that carried passengers; most freight trains, though, did not. The BCR\&N warned prospective patrons that "Freight trains shown on this Time Card will carry passengers only when provided with Tickets." Conductors, then, were not permitted to collect cash fares, probably because they were a nuisance and employees' honesty (or lack thereof) could not be easily monitored. And as with some contemporary carriers, the road sold advertising space in its public timetables; it surely did so to offset the cost of distributing thousands of free copies to the public.

This particular Iowa Route timetable holds considerable value. Most of all, it tells much about the nature of this nearly forgotten road. Individual schedules note station stops-an indication that depots or at least shelters once existed there 
and, of course, length of travel and frequency of service. Take the BCR\&N's "Iowa City Division." This branch line ran twenty-one miles from a main line connection at Elmira, through Iowa City, to Iowa Junction, where it joined the Muscatine-to-Montezuma trackage. The company operated three through trains daily except Sunday, including a mixed one, and it provided additional service to either Elmira or Iowa Junction. Speeds were modest; BCR\&N trains were hardly "ballast scorchers." Yet they were not unusually slow by late nineteenth century standards. Train Number 4, the "Burlington Passenger," for example, covered the distance between Elmira and Iowa Junction in fifty minutes or about twenty-five miles per hour. The way-freight, not surprisingly, traveled at a much more leisurely rate: it took two hours and twenty minutes to cover the twenty-one miles.

This 1892 folder tells more. It indicates, for one thing, that the United States Express Company, one of several privatelyowned package forwarders before World War I, served communities along this road. Even advertisements are educational. Since railroads, like the $B C R \& N$, pushed to open the transMississippi west to settlement, land promoters understandably seized this opportunity to inform travelers seeking new homes that they could provide desirable real estate. Similarly, these advertisements reveal the prose and selling techniques common to the period. For example, DeSmet, South Dakota, realtor C.C. Hortman, who offered farms in Kingsbury and Clark counties, believed that he could attract attention with a clever word-gram. And perhaps he did.

Not only did the Iowa Route distribute public timetables, complete with snappy advertisements, it also produced operating ones. As the company noted on each cover: "For the Government and Information of Employes [sic] Only. Not for Information of the Public." Customarily railroads listed various "classes" of trains. In the case of BCR\&N "Time Table No. 97," effective 4 June 1899, two classes of passenger trains ("first" and "second") and a local freight chugged over the Iowa City Division. What is particularly valuable about this genre of 


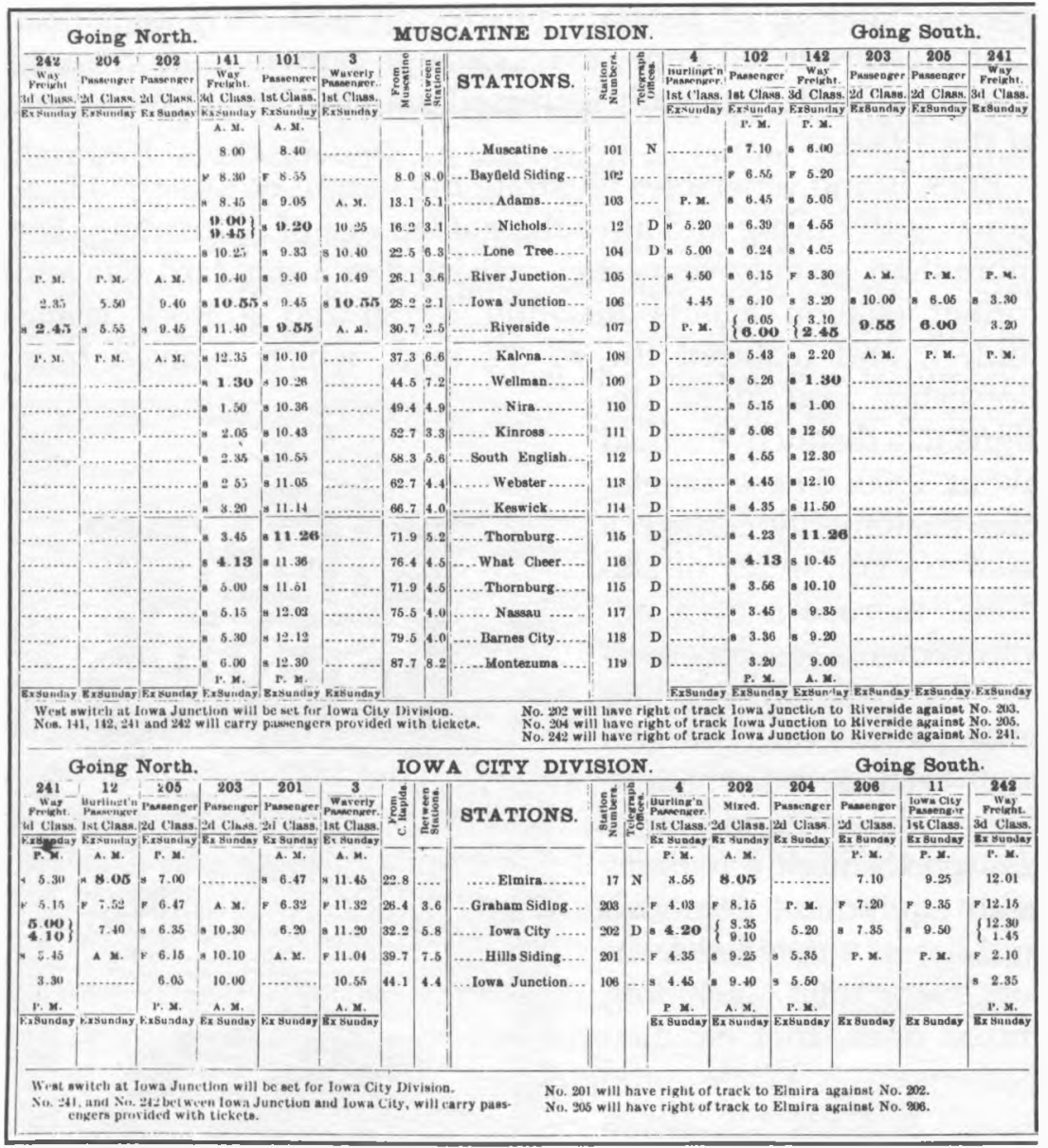

schedule is that it gives details of operations, including exact mileage between stations, location of telegraph offices, and times for freight movements.

More modern public timetables continue the tradition of those published during the late nineteenth century. Yet, these schedules commonly appear in a standard size ( 9 by 4 inches), sport a corporate logo on the cover (frequently in color), feature local and/or system maps, and contain more pages-after all, 
system-building of the late nineteenth and early twentieth centuries produced large, even gigantic carriers, and intercity passenger traffic generally increased until the Great Depression of the 1930s.

Rock Island timetables illustrate the nature of these publications, both during and after the golden age of railroading. For more than seventy years they consisted of a standard size and format (station agents instantly recognized a Rock Island folder), and featured the road's logo, which evolved from horseshoe and globe designs to a distinctive shield about 1900 . These timetables customarily contain a system map, index of stations, railroad-related advertisements (usually used as filler material), sleeping and parlor car charges, and related information. They also provide condensed through schedules with equipment notations and list in a detailed fashion every train, including mixed ones, that handled passengers. While the length of these timetables varied, they usually exceeded thirty pages until the 1960s. But as the Rock Island withdrew passenger runs, the schedules shrank noticeably. The company's last public timetables resemble those of the early and midnineteenth century: they

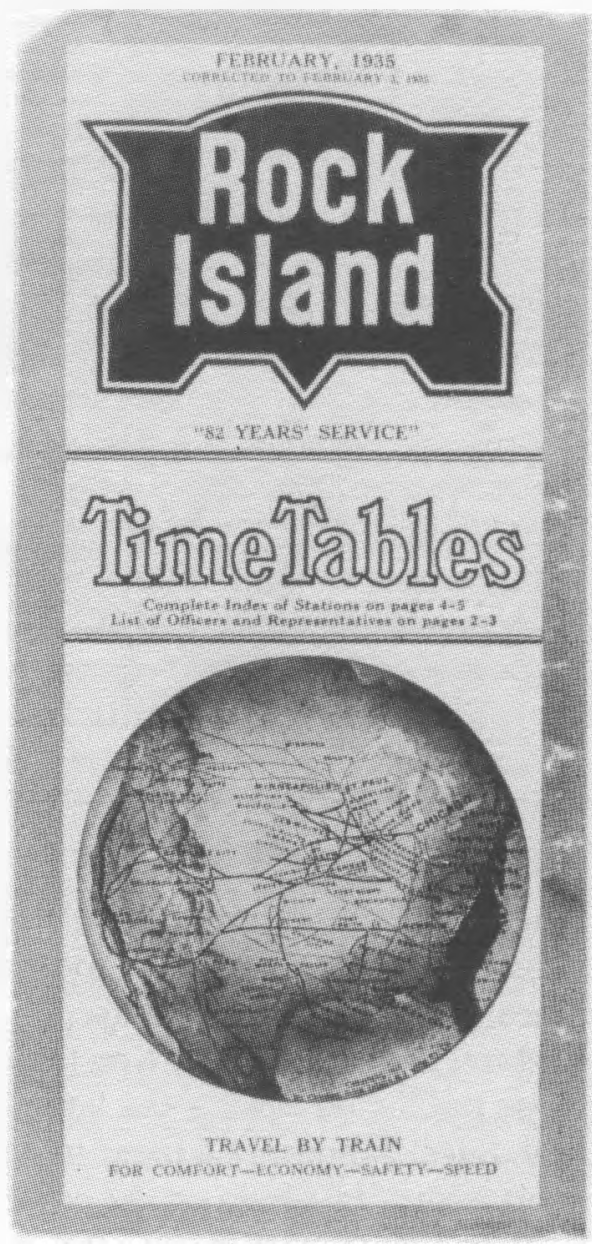


were merely 9 by 4 inch cards with schedules on one side and travel information on the other.

Contemporary operating timetables also became highly standardized, although with an important variation. Those printed before World War II commonly came in a large-style format, measuring approximately 11 by 14 inches. Some roads used even larger ones, appropriately dubbed "bed-sheets." Later these timetables took a less awkward 9 by 10 inch form, and so they could be folded easily to fit the pocket of a trainman's uniform or overalls. Ultimately, most came in a reduced (usually 5 by 9 inch) size.

Whether they used large or small timetables, railroads issued these employee timecards by operating divisions or perhaps by operating districts within a division. Only after passenger trains disappeared and decisions were made to dispatch freight trains as "extras," that is without a printed schedule, did these timetables encompass an entire railroad. (Smaller roads, especially shortlines, had long used system-wide timecards). Companies marked them sequentially, frequently with big colored Arabic numerals, and commanded personnel to "Destroy All Time Tables of Previous Date." They did not want their employees to operate trains with an out-of-date timetable: Disaster might result, for times printed in these schedules gave crews legal rights if obeyed properly.

More so than employee timetables from the last century, twentieth century ones minutely detail railroading over a particular stretch of trackage. Take the case of Rock Island's "No. 6" timecard for the First District of the Des Moines Division, which took effect on 5 June 1938. The page that includes "Main Line Westward...Sub-Division 4" shows passenger trains (first-class) with names and numbers and freight trains (second-class), also with names - for example, "Chicago, Colorado, Calif. Red Ball" and "East Iowa Red Ball" - and numbers. The timetable also notes car capacities of sidings and other tracks, distances between stations and railroad junctions 
MKNS LDV WESTWMRD

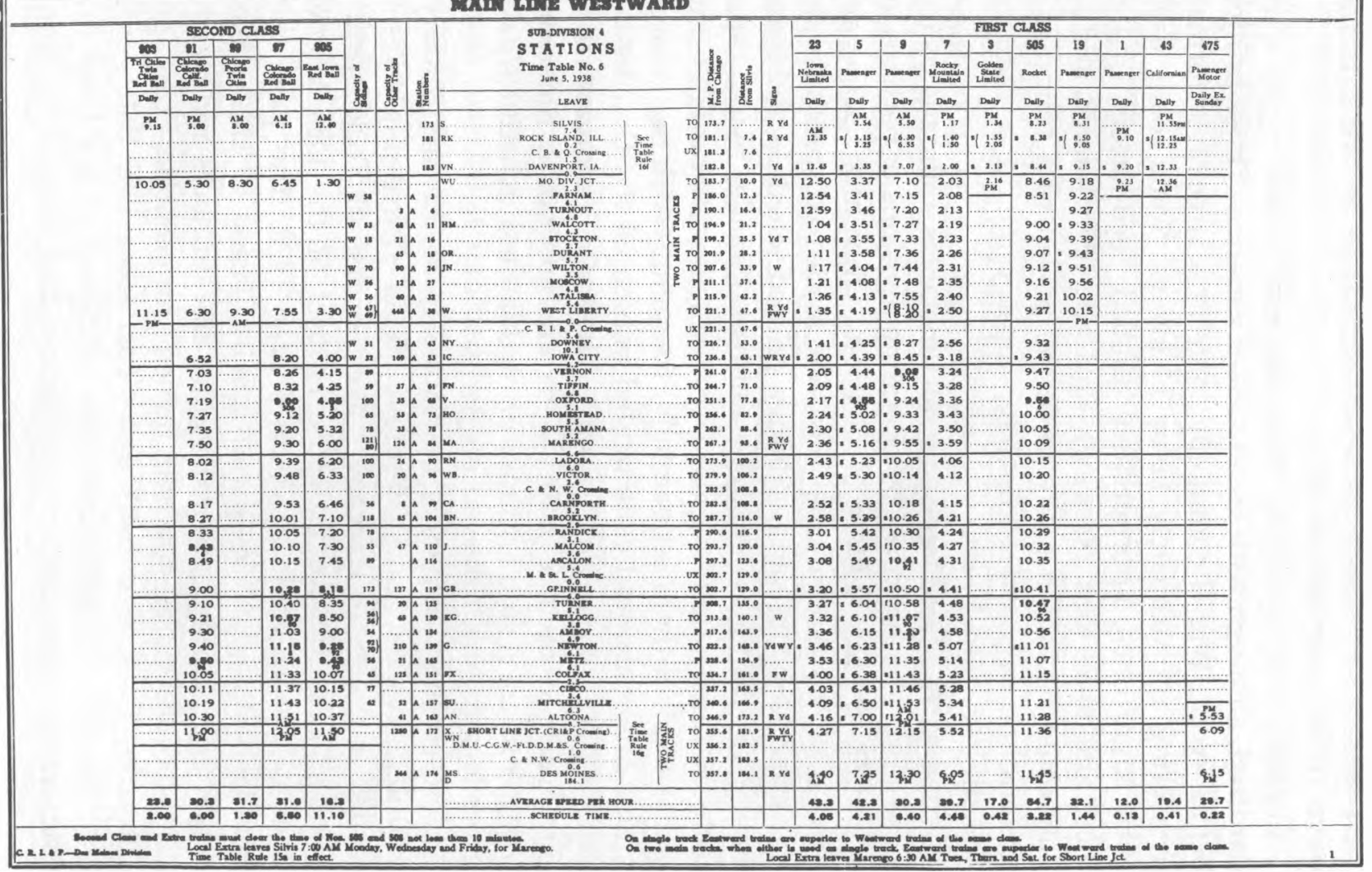

http://ir.uiowa.edu/bai/vol53/iss1 
and crossings, and train-support facilities. Marengo, Iowa, for instance, had both a water tank [W] and coal chute $[\mathrm{F}]$ for servicing steam locomotives.

Employee timetables provide even more data. They list names of operating officials and physicians, including "local surgeons"; note particular operating instructions, for example speed restrictions; indicate hours when agents are on duty; and contain "Special Instructions" for additional rules and commentary about train operations.

Unlike public timetables, employee timetables are more difficult to find. This is true for both the University's Special Collections and other research libraries. The explanation unquestionably involves that universal instruction to personnel to destroy previous issues. And, too, railroads printed fewer of these timetables. A large ("Class 1") carrier, like the Rock Island, generally ordered 10,000 to 20,000 copies of a public timetable issue but fewer than a thousand of an operating one.

Uses for old timetables are considerable. They run the gamut from the obvious - to check on the number of passenger and/or freight trains that served a community at a particular point in time - to the less readily apparent. Perhaps someone involved in historic preservation wishes to research a local depot. An operating schedule would tell about staffing, satellite facilities and other matter involving daily business. This information, coupled with oral histories, newspapers, photographs, maps, and government reports, can flesh out a building's past. In addition to utilitarianism, there exists an aesthetic dimension. Railroad enthusiasts, most of all, find considerable pleasure in examining such artifacts. Some public timetables are truly works of art, and all make possible a mental trip by train through the past. 